\title{
HUBUNGAN PERSEPSI MAHASISWA TENTANG PEMBELAJARAN KLINIK DENGAN KINERJA MAHASISWA DALAM PENDOKUMENTASIAN KEPERAWATAN
}

\author{
Dian Novita, Sara Tania* \\ Program Studi Sarjana Keperawatan, \\ Sekolah Tinggi Ilmu Kesehatan Wijaya Husada Bogor \\ *)E-mail: wijayahusadaakd@gmail.com
}

Diterima: Januari 2018, diterbitkan: April 2018

\begin{abstract}
ABSTRAK
Tujuan penelitian: mengetahui hubungan antara persepsi mahasiswa tentang pembelajaran klinik dan kinerja mahasiswa dalam pendokumentasian keperawatan. Metode: penelitian ini bersifat deskriptif analitik dengan pendekatan cross sectional. Populasi penelitian adalah semua mahasiswa D-3 Keperawatan tingkat 3 yang sudah pernah melaksanakan praktik klinik keperawatan, yaitu sebanyak 93 mahasiswa, dengan teknik total sampling. Alat ukur yang digunakan adalah kuesioner persepsi mahasiswa yang dibuat sendiri oleh peneliti dan lembar checklist kinerja yang diadopsi dari instrumen A Depkes yang telah diuji validitas dan reliabilitasnya. Pengumpulan data untuk menilai persepsi sebanyak 19 pernyataan dan lembar checklist sebanyak 25 pernyataan untuk menilai kinerja mahasiswa. Pengambilan data penelitian dilakukan pada September 2017. Analisis data menggunakan uji univariat dan bivariat dengan uji Cramer's V. Hasil: Hasil penelitian menunjukkan dari 93 responden sebanyak 60 (64,5\%) mempunyai persepsi positif tentang pembelajaran kinik dan sebanyak $49(52,7 \%)$ responden dengan kinerja yang redah dalam pendokumentasian keperawatan. Ada hubungan antara kedua variabel dengan nilai $p$ value $=0,004$ dan nilai $O R$ yaitu 3,733. Diskusi: persepsi merupakan salah satu faktor psikologis yang dapat memengaruhi kinerja seseorang. Kesimpulan: mahasiswa yang memiliki persepsi positif terhadap pembelajaran kinik akan menghasilkan kinerja yang tinggi dalam pendokumentasian keperawatan. Diharapkan dalam pelaksanaan praktik klinik selalu menjalin komunikasi efektif dengan pembimbing, baik dari akademik maupun dari lahan praktek serta meningkatkan kinerjanya sesuai dengan pedoman yang sudah ditentukan.
\end{abstract}

Kata Kunci: persepsi, kinerja, dokumentasi keperawatan

\section{CORRELATION BETWEEN STUDENT PERCEPTION OF CLINICAL LEARNING AND STUDENT PERFORMANCE IN NURSING DOCUMENTATION}

\section{ABSTRACT}

Objective: To identify the correlation between student perception of clinical learning and student performance in nursing documentation. Methods: This research is descriptive analytic with cross sectional approach. The population was all third-year students of DIII Nursing who had performed clinical nursing practice, numbering 93 students, taken using total sampling. The instruments used were a student perception questionnaire made by the researcher and a performance checklist adopted from the Ministry of Health's instrument A of which validity and reliability had been tested. Data collection consisted of 19 statements to assess perceptions and a checklist sheet containing 25 statements to assess student performance. The data were collected in September 2017. They were analyzed using univariate and bivariate tests with Cramer's $V$ test. Results: The research results indicated that out of the 93 respondents, 60 respondents (64.5\%) had positive perceptions of kinetic learning and 49 respondents (52.7\%) had poor performance in nursing documentation. There was a correlation between the two variables with $p$ value of 0.004 and OR value of 3.733. Discussion: Perception is one of the psychological factors that may affect a person's performance. Conclusion: Students who have positive perceptions of kinetic learning will likely produce high performance in nursing documentation. It is expected that during 
the implementation of clinical practice, students always establish effective communication with supervisors, both from the academic and from the field of practice, and improve their performance in accordance with the guideline that have been set. Keywords: perception, performance, and nursing documentation.

\section{LATAR BELAKANG}

Pendidikan tenaga kesehatan bertujuan untuk menghasilkan tenaga kesehatan dalam jumlah, jenis, dan kualitas yang sesuai dengan kebutuhan upaya pelayanan kesehatan. Untuk memenuhi jumlah dan jenis tenaga kesehatan sudah terealisasikan dengan telah banyak lembaga penyelenggara pendidikan tenaga kesehatan. Akan tetapi, jumlah dan jenis tenaga kesehatan tersebut tidak selalu diikuti dengan kualitas lulusan yang diharapkan (Simamora, 2009).

Perawat adalah seseorang tenaga kesehatan professional yang mempunyai kemampuan, tanggung jawab, dan kewenangan melaksanakan asuhan keperawatan pada berbagai jenjang pelayanan keperawatan (Nursalam, 2008). Sebagai upaya untuk dapat memberikan pelayanan dengan penuh tanggung jawab, salah satu langkah yang dapat ditempuh ialah terselenggaranya kegiatan pencatatan dan pelaporan yang baik dan benar. Dalam keperawatan pencatatan dan pelaporan ini lebih sering disebut sebagai pendokumentasian asuhan klinik keperawatan (Baumgartner et al., 2017).

Menurut Rohman \& Walid (2009), asuhan profesional keperawatan harus mampu melaksanakan proses keperawatan dengan tepat dan benar. Pemahaman mahasiswa terhadap proses perawatan sangat penting karena topik ini akan menjadi bagian yang sangat penting dalam pelaksanaan asuhan keperawatan. Perbedaan asuhan yang profesional dengan asuhan tradisional terletak pada penggunaan proses keperawatan. Kemampuan perawat dalam menerapkan proses keperawatan dalam asuhannya sudah tidak dapat ditawar lagi apabila ia meyakini bahwa asuhannya adalah asuhan keperawatan dapat memfasilitasi proses belajar dengan memberikan kesempatan kepada mahasiswa untuk menerapkan asuhan keperawatan di bawah pengawasan pembimbing klinik dan secara bertahap menumbuhkan kepercayaan diri mahasiswa melalui proses belajar (Departemen Kesehatan Republik Indonesia/ Depkes RI, 2006).

Menurut Rohmah (2010), bahwa pembelajaran klinik di rumah sakit bagi mahasiswa yang baru pertama kali menjalani praktik klinik keperawatan dalam menerapkan asuhan keperawatan sering kali mengalami banyak hambatan, antara lain belum beradaptasi dengan kondisi nyata berhadapan dengan pasien secara langsung, hubungan dengan perawat senior di ruangan masih kaku, kemampuan melakukan dokumentasi belum sepenuhnya kompeten sehingga kompetensi klinik tidak dapat dicapai secara maksimal.

Keberadaan pembimbing dalam pembelajaran klinik sangat diperlukan oleh mahasiswa untuk mengadakan konsultasi dan bimbingan yang nantinya akan memengaruhi kualitas laporan Praktik Klinik Keperawatan. Pada pelaksanaan pembelajaran klinik, pembimbing melakukan bimbingan dan observasi tentang kemampuan interpersonal dalam memberikan asuhan keperawatan secara langsung kepada klien, serta membimbing mahasiswa dalam pendokumentasian asuhan keperawatan sesuai kasus penyakit kelolaan mahasiswa (Purwani, 2010).

Oleh karena itu, perlu dikembangkan persepsi yang baik terhadap profesi 
keperawatan sehingga mengetahui dan paham tentang perkembangan pelayanan, peran fungsi dan kompetensi perawat, kode etik dan standar pelayanan keperawatan. Melalui persepsi dan perilaku dapat diidentifikasi apa yang dibutuhkan dan diinginkan sehingga ditemukan peluangpeluang yang memungkinkan dapat dijadikan sebagai dasar untuk menyampaikan informasi mengenai sesuatu sehingga tidak terjadi salah persepsi (Mukhtar, Nursalam, \& Kurniawati, 2016).

Berdasarkan penelitian yang dilakukan Bjork et al. (2014), diperoleh data 65\% ( $n=41$ mahasiswa) mempunyai persepsi positif terhadap pembelajaran klinik di lingkungan rumah sakit dan $100 \%$ dengan penilaian yang baik. Pembelajaran dan kinerja mahasiswa mencerminkan sikap profesional, perilaku, etika, dan standar pembimbing.

Data dari STIKes Wijaya Husada Bogor (2016) tentang Laporan Evaluasi Praktik Klinik Keperawatan STIKes Wijaya Husada (2016) menunjukkan bahwa dari 93 mahasiswa, terdapat 40 mahasiswa yang mengadakan bimbingan ke pembimbing lahan praktik maupun ke institusi akademik sesuai pedoman praktik klinik keperawatan setiap pembimbing mengadakan supervisi ke lahan praktik, 50 mahasiswa belum siap dalam pembuatan dokumentasi hasil kelolaan pasien dengan alasan masih dibuat draf di kertas, baru membuat laporan pendahuluan, atau alasan jika konsultasi ke pembimbing lahan praktik belum bisa karena mereka sibuk dengan aktivitasnya di lahan praktik.

Pada pembuatan dokumentasi asuhan keperawatan, 48 mahasiswa dalam pembuatan laporan berdasarkan laporan dari kakak kelas ataupun laporan uji komprehensif yang ada di perpustakaan maupun data yang mereka peroleh dari hasil catatan medis/ catatan perawatan. Dalam penyerahan laporan dokumentasi asuhan keperawatan,
35 mahasiswa menyerahkan tepat waktu, 55 mahasiswa menyerahkan laporan pembuatan dokumentasi asuhan keperawatan pada akhir periode praktik selesai sehingga jika ada revisi, pendokumentasian yang dibuat sesuai dengan kondisi penyakit klien tidak memungkinkan dengan alasan klien sudah pulang ataupun waktu praktik sudah selesai (STIKes Wijaya Husada, 2016). Berdasarkan paparan tersebut, maka peneliti tertarik untuk meneliti "hubungan antara persepsi mahasiswa tentang pembelajaran klinik dengan kinerja mahasiswa dalam pendokumentasian keperawatan"

\section{METODE}

Rancangan penelitian yang digunakan pada penelitian ini ialah deskriptif analitik kuantitatif dengan pendekatan cross sectional. Pengumpulan data dalam penelitian ini menggunakan kuesioner dan lembar checklist. Kuesioner untuk mengetahui persepsi mahasiwa terhadap pembelajaran klinik berjumlah 19 pernyataan yang dibuat sendiri oleh peneliti berdasarkan sumber rujukan dari Boekaerts et al. (2010), dengan skala Likert: Sangat Setuju (4), Setuju (3), Ragu-ragu (2), Tidak Setuju (1), Sangat Tidak Setuju (0). Skala penilaian nominal yang dikategorikan sebagai berikut. (1) Persepsi positif jika nilai T skor yang diperoleh responden dari kuesioner $>T$ mean. (2) Persepsi negatif jika nilai T skor yang diperoleh responden dari kuesioner $\leq T$ mean.

Checklist untuk mengetahui kinerja mahasiswa dalam pendokumentasian asuhan keperawatan sebanyak 25 pernyataan yang diadopsi dari instrumen A Depkes (Nursalam, 2008). Penilaian yaitu dengan cara jika dilakukan benar semua (2), dilakukan benar sebagian (1), tidak dilakukan (0). Skala penilaian nominal yang dikategorikan sebagai berikut: (1) Tinggi, jika skor > mean dan (2) Rendah, jika skor $\leq$ mean. 
Uji validitas dilakukan pada 30 mahasiswa S1 Keperawatan pada tanggal 30 Agustus 2017 dengan menggunakan pearson product moment. Hasil uji validitas dinyatakan valid karena $r$ tabel $>r$ hitung $(0,365)$. Reliabilitas pada kuesioner persepsi mahasiswa dalam penelitian ini diuji dengan menggunakan Alpha Cronbach, didapatkan nilai 0,976. Maka kuesioner persepsi dinyatakan reliable.

Sebelum dilakukan pengambilan data, maka peneliti meminta kesediaan responden untuk berpartisipasi dalam penelitian dan menyatakan persetujuannya dengan menandatangani lembar kesediaan menjadi responden penelitian. Pengambilan data penelitian ini dilakukan pada tanggal 9 September 2017 selama sehari pada mahasiswa Tingkat III Prodi DIII Keperawatan STIKes Wijaya Husada. Lokasi penelitian ini dilakukan di STIKes Wijaya Husada Bogor. Populasi dalam penelitian ini adalah mahasiswa tingkat 3 Prodi D3 Keperawatan STIkes Wijaya Husada Bogor yang sudah melaksanakan praktik klinik keperawatan, jumlah populasinya 93 mahasiswa.

Kriteria inklusi penelitian adalah mahasiswa D-3 Keperawatan tingkat 3 yang sehat yang bersedia menjadi responden serta sudah pernah melaksanakan praktik klinik keperawatan. Sementara itu, kriteria eksklusinya ialah mahasiswa yang tidak bersedia menjadi responden atau mengundurkan diri sebagai sampel karena alasan tertentu. Pengambilan sampel dilakukan dengan cara total sampling, yaitu semua mahasiswa D-3 Keperawatan tingkat 3 dijadikan sebagai responden dalam penelitian, yaitu sebanyak 93 responden. Setelah jumlah sampel diketahui, kemudian dilakukan langkah-langkah untuk responden pertama diberi kode 1, sampel nomor berikutnya diberi kode 2, dan seterusnya sampai semua sampel terpenuhi 93 responden.

Analisis yang dilakukan berupa analisis univariat untuk mengetahui gambaran deskriptif dari data-data yang dikumpulkan antara lain jumlah dan persentase persepsi mahasiswa dan kinerja mahasiswa. Sementara itu, analisis bivariat dilakukan untuk melihat hubungan antara kedua variabel, yaitu persepsi dan kinerja. Untuk maksud tersebut, uji statistik yang digunakan adalah uji Cramer's V. hasilnya signifikan jika nilai $p<0,05$ (Sugiyono, 2012).

\section{HASIL}

Berdasarkan data karakteristik responden penelitian, dari 93 responden diperoleh ratarata responden berumur 21-24 tahun (95\%), dengan $75,3 \%$ di antaranya berjenis kelamin perempuan.

\section{Hasil Data Distribusi Frekuensi Persepsi Mahasiswa tentang Pembelajaran Klinik dan kinerja mahasiswa dalam Pendokumentasian Keperawatan}

Tabel 1. Distribusi frekuensi persepsi mahasiswa tentang pembelajaran klinik dan kinerja mahasiswa dalam pendokumentasian keperawatan $(n=93)$

\begin{tabular}{ccc} 
Variabel & Frekuensi & Persentase (\%) \\
\hline Persepsi & & \\
Positif & 60 & 64,5 \\
Negatif & 33 & 35,5 \\
Kinerja & & \\
Tinggi & 44 & 47,3 \\
Rendah & 49 & 52,7 \\
\hline
\end{tabular}

Pada Tabel 1 dapat dilihat dari 93 responden, didapatkan 60 responden $(64,5 \%)$ dengan persepsi yang positif terhadap pembelajaran klinik dan didapatkan rata-rata $49(52,7 \%)$ dengan kinerja yang rendah dalam pendokumentasian keperawatan. 


\section{Hasil Data Hubungan Persepsi Mahasiswa tentang Pembelajaran Klinik dengan Kinerja Mahasiswa dalam Pendokumentasian Asuhan Keperawatan}

Tabel 2. Hubungan persepsi mahasiswa tentang pembelajaran klinik dengan kinerja mahasiswa dalam pendokumentasian keperawatan $(n=93)$

\begin{tabular}{|c|c|c|c|c|c|c|}
\hline \multirow{3}{*}{ Persepsi } & \multicolumn{4}{|c|}{ Kinerja } & \multirow{3}{*}{$\begin{array}{l}p \\
\text { value }\end{array}$} & \multirow{3}{*}{$\begin{array}{l}\text { OR }(95 \% \\
\text { Cl) }\end{array}$} \\
\hline & \multicolumn{2}{|c|}{ Tinggi } & \multicolumn{2}{|c|}{ Rendah } & & \\
\hline & $F$ & $\%$ & $F$ & $\%$ & & \\
\hline Positif & 35 & 58,3 & 25 & 41,7 & & $\begin{array}{l}3,733 \\
(1,485- \\
9,388)\end{array}$ \\
\hline Negatif & 9 & 27,3 & 24 & 72,7 & 0,004 & \\
\hline Total & 44 & 47,3 & 49 & 52,7 & & \\
\hline
\end{tabular}

Berdasarkan Tabel 2 dapat dilihat dari 93 responden, didapatkan sebanyak $35(58,3 \%)$ mahasiswa dengan persepsi yang positif terhadap pembelajaran klinik dan dengan kinerja yang tinggi dalam pendokumentasian asuhan keperawatan. Hasil uji statistik didapatkan nilai $p$ value $=0,004$ yang artinya ada hubungan antara persepsi mahasiswa terhadap pembelajaran klinik dengan kinerja mahasiswa dalam pendokumentasian asuhan keperawatan. Hasil nilai OR, yaitu 3,733 artinya persepsi mahasiswa yang positif akan berpeluang memberikan kinerja yang tinggi sebanyak 3,733 kali $\approx 4$ kali dibandingkan pada mahasiswa dengan persepsi yang negatif terhadap pembelajaran klinik.

\section{DISKUSI}

Penelitian ini menunjukkan sebanyak $64,5 \%$ responden memiliki persepsi positif tentang pembelajaran kinik dan 52,7\% responden memiliki kinerja yang rendah dalam pendokumentasian keperawatan. Hal ini sejalan dengan penelitian Bjork et al. (2014), diperoleh data 65\% ( $n=41$ mahasiswa), mempunyai persepsi positif terhadap pembelajaran klinik di lingkungan rumah sakit dan $100 \%$ dengan penilaian yang baik. Hal yang sama dikemukakan oleh Gibson (2009/2010), bahwa persepsi merupakan salah satu faktor psikologis yang dapat memengaruhi kinerja seseorang.

Menurut Boekaerts et al. (2010) persepsi bersifat individual dan sangat beragam antara satu individu dan lainnya yang mengalami realitas yang sama. Seseorang dapat memiliki persepsi yang berbeda terhadap objek yang sama. Dengan adanya individual differences, stimulus yang diterima siswa berupa metode pembelajaran akan berbeda baik secara afeksi maupun kognisi. Ada siswa yang memiliki persepsi yang positif dan ada pula siswa yang memiliki persepsi yang negatif terhadap pembelajaran.

Selain persepsi terhadap kepuasan kebutuhan personal dalam kaitannya dengan instruksi yang diberikan, yaitu dengan mengetahui nilai pelajaran dan berhubungan dengan jurusan atau pekerjaan yang ingin ditekuni, pendapat siswa mengenai efisien atau efektifnya suatu metode pembelajaran memengaruhi motivasi belajar siswa (Boekaerts et al., 2010). Ketika seseorang merasa bahwa metode pembelajaran tersebut efektif dan efisien ini akan meningkatkan motivasi dan kinerjanya dalam belajar dan sebaliknya jika seseorang merasa metode 
pembelajaran tersebut tidak efektif dan efisien, motivasi dan kinerja belajarnya akan turun. (Boekaerts et al., 2010).

Hal tersebut sejalan dengan penelitian yang dilakukan Purwani (2010), di mana sebanyak 35 responden $(70 \%)$ mempunyai persepsi yang baik tentang pembimbingan klinik, dan 15 responden $(30 \%)$ mempunyai persepsi sedang terhadap pembimbingan klinik, sementara 35 responden (70\%) memiliki motivasi belajar yang tinggi, sedangkan 15 responden (30\%) memliki motivasi belajar yang sedang. Hasil uji statistik menunjukkan nilai $\mathrm{p}$ value $<0,001$. Dengan demikian, diketahui bahwa terdapat hubungan yang signifikan antara persepsi terhadap pembimbingan klinik dengan motivasi belajar mahasiswa yang sedang melaksanakan praktik di RSUD Dr. Moewardi Surakarta.

Dengan demikian, dapat disimpulkan bahwa mahasiswa yang memiliki persepsi yang positif terhadap pembelajaran klinik merasa bahwa melalui pembelajaran klinik tumbuh kebahagiaan, minat, dan antusiasme mahasiswa; melalui tugas yang diberikan, mahasiswa merasa kebutuhan personalnya terpuaskan. Salah satu kebutuhan personal mahasiswa ialah harapan akan pekerjaan yang akan ditekuninya di masa depan sejak mereka telah memulai peminatan terhadap dunia keperawatan. Selain itu, mahasiswa yang memiliki persepsi positif terhadap pembelajaran klinik menganggap bahwa metode pembelajaran yang diberikan oleh pembimbing lebih nyata, efektif, dan efisien sehingga dapat meningkatkan motivasi mahasiswa dalam mempelajari ilmu keperawatan (Boekaerts et al., 2010).

Sebaliknya, mahasiswa yang memiliki persepsi yang negatif terhadap pembelajaran klinik merasa bahwa melalui pembelajaran klinik kebutuhan personalnya tidak terpuaskan sehingga tidak menumbuhkan kebahagiaan, minat, dan antuasime mahasiswa terhadap pembelajaran klinik (Boekaerts et al., 2010). Menurut Meyer, Nel, \& Downing (2016), sejak mahasiswa telah memilih jurusan keperawatan, mereka berharap bahwa tugas atau instruksi yang diberikan oleh dosen/pembimbing tidak hanya dapat diaplikasikan pada kehidupan sehari-hari, tetapi juga berhubungan dengan jurusan atau pekerjaan yang ingin ditekuni di masa depan. Ketika mahasiswa tidak dapat melihat bagaimana teori yang dipelajarinya diaplikasikan dalam bidang ilmu dan pekerjaan, motivasi dan kinerja belajarnya dapat menurun. Blažun et al., (2015) menjelaskan bahwa mahasiswa juga menganggap ketika metode pembelajaran yang diberikan oleh dosen/pembimbing tidak efektif dan efisien akan menurunkan motivasi dan kinerjanya. Kegiatan pendokumentasian asuhan keperawatan sangatlah penting dilakukan oleh perawat karena berguna untuk kepentingan klien, perawat, dan tim kesehatan lain dalam memberikan pelayanan kesehatan dengan dasar komunikasi akurat dan lengkap dengan tanggung jawab perawat (Hidayat, 2012).

Diperlukan penelitian lanjut dengan dilakukannya pengendalian terhadap faktor confounding lainnya, seperti usia dan jenis kelamin, sehingga hasil yang didapatkan benar-benar faktor murni yang memengaruhi kinerja.

\section{SIMPULAN}

Persepsi yang positif terhadap pebelajaran klinik akan menghasilkan kinerja yang tinggi dalam pendokumentasian asuhan keperawatan pada mahasiswa. Diharapkan dalam pelaksanaan praktik klinik selalu menjalin komunikasi efektif dengan pembimbing baik dari akademik maupun dari lahan praktik, dan meningkatkan kinerjanya sesuai dengan pedoman yang sudah ditentukan. 


\section{DAFTAR PUSTAKA}

Baumgartner, R., Ståhl, C. H., Manninen, K., Hedman, A. R. (2017). Assessment of nursing students in clinical practice an intervention study of modified process. Journal of Nursing Education and Practice, 7(11): 111-122.

Bjork, I. T., Berntsen, K., Brynildsen, G., Hestetun, M. (2014). Nursing students perceptions of their clinical learning environment in placements outside traditional hospital settings. Journal of Clinical Nursing, 23(19): 58-67. B

Blažun, H., Kokol, P., \& Vošner, J. 2015. Reserch literature production on nursing competences from 1981 till 2012: A bibliometric snapshot. Journal of Nurse Education Today, 35(5): 673-679.

Boekaerts, M., Martens, R. L., Dusseldorp, E., \& Nuland, H. J. C. (2010). Exploring the motivation jungle: Predicting performance on a novel task by investigating constructs from different motivation perspectives in tandem. International Journal of Psychology, 45(4): 250-259.

Departemen Kesehatan Republik Indonesia. (2006). Pedoman pengajaran bagi pembimbing klinik. Jakarta: Pusat Pendidikan Tenaga Kesehatan.

Gibson, J. L., John, M. I., \& James, H. D. Jr. (2010). Organisasi, perilaku, struktur proses. (Alih Bahasa: N. Ardiani). Jakarta: Bina Rupa Aksara. (Buku Asli diterbitkan 2009).

Hidayat, A. A. A. (2012). Pengantar dokumentasi proses keperawatan. Jakarta: EGC.

Meyer, G. E., Nel., E., \& Downing, C. (2016). Basic student nurse perceptions about clinical instructor caring. Journal of Health SA Gesondheid, 21: 444-452.

Mukhtar, M., Nursalam \& Kurniawati, N. D. (2016). Persepsi mahasiswa keperawatan indonesia tentang perilaku caring dan karakteristik pengajaran pembimbing akademik. Jurnal Ners, 11(2): 186-194.

Nursalam. (2008). Proses dan dokumentasi keperawatan: konsep dan praktik (Edisi 2). Jakarta: Salemba Medika.

Purwani, F. (2010). Hubungan antara persepsi mahasiswa terhadap pembimbingan klinik dan motivasi belajar praktik klinik di RSUD Dr. Moewardi Surakarta. Retrieved from https://digilib.uns.ac.id/ dokumen/detail/22798/HubunganAntara-Persepsi-Mahasiswa-TerhadapPembimbingan-Klinik-dan-MotivasiBelajar-Praktik-Klinik-di-Rsud-DrMoewardi-Surakarta

Rohman, N. \& Walid, S. (2009). Proses keperawatan: Teori dan aplikasi: Yogyakarta: Ar-Ruzz Media.

Rohman, N. (2010). Integrasi proses keperawatan dalam pembelajaran klinik keperawatan one to one teaching and feedback. The Indonesian Journal of Health Science, 1(1): 51-60.

Simamora, R. H. (2009). Buku ajar dalam keperawatan. Jakarta: EGC.

STIKes Wijaya Husada Bogor. (2016). Laporan evaluasi praktik klinik keperawatan tahun 2016. (Unpublished Document).

Sugiyono. (2012). Metode penelitian kuantitatif kualitatif dan $R \& D$. Bandung: Alfabeta. 